\title{
Pancreatic Cancer: Progress in Systemic Therapy
}

\author{
Lukas Perkhofer Thomas J. Ettrich Thomas Seufferlein \\ Department of Internal Medicine I, Ulm University Hospital, Ulm, Germany
}

\section{Key Words}

Chemotherapy · Pancreas · Pancreatic cancer · Therapy

\begin{abstract}
Background: Pancreatic ductal adenocarcinoma (PDAC) is a leading cause of cancer-related deaths in the Western world. Due to lack of specific symptoms and no accessible precursor lesions, primary diagnosis is commonly delayed, resulting in the identification of only $15-20 \%$ of patients with potentially curable disease. The major limiting factor is an already locally advanced or metastatic disease at the time of diagnosis. Consequently, systemic therapy forms the backbone of treatment strategy for the majority of patients. Summary: A deeper understanding of the molecular characteristics of pancreatic cancer has led to the identification of several potential therapeutic targets. A variety of targeted therapies are currently under clinical evaluation as single agents or in combination with chemotherapy for PDAC. This review highlights the current state of chemotherapy in pancreatic cancer and provides an outlook on its future perspectives. Key Message: This review focuses on the current chemotherapy regimens for the systemic treatment of PDAC. Practical Implications: Various neoadjuvant approaches have been explored, including chemoradiation, chemotherapy followed by chemoradiation or intensified chemotherapy without defining a standard of care so far. The standard of care is gemcitabine or 5-fluorouracil. The oral fluoropyrimidine S-1 may be a promising new agent in this setting. For first-line treatment of metastatic pancreatic cancer, no targeted therapy has yet demonstrated clinical benefit apart from the combination of the tyrosine kinase inhibitor erlotinib plus gemcitabine. Recently, novel chemotherapeutic regimens such as FOLFIRINOX and gemcitabine plus nanoparticle albumin-bound paclitaxel have been introduced. Both combinations have proved to be superior to the standard gemcitabine regimen. For second-line treatment the combination of 5-fluorouracil/leucovorin and oxaliplatin yields improved results compared to best supportive care.




\section{Introduction}

Pancreatic ductal adenocarcinoma (PDAC) is still the most lethal cancer in the Western world [1]. Whereas survival times in various other solid tumor entities have constantly improved, only subtle advances were achieved in PDAC over the last decade [2]. Moreover, forecasts predict only a marginal improvement in overall survival (OS) by 2030 when pancreatic cancer shall be the third leading cause of cancer death due to a steady rise in incidence [3].

The only potentially curative approach for PDAC is surgery. Only $15-20 \%$ of patients are eligible for surgery at primary diagnosis. The major limiting factor is an already locally advanced or metastatic disease at the time of diagnosis. Consequently, the 5-year OS does not exceed $7 \%[1,2]$. After surgical resection and adjuvant chemotherapy the OS rate is about $20 \%[1,4]$. To improve this outcome a neoadjuvant treatment strategy may be helpful, and several small trials have been conducted [5-11]. As yet, there is no established standard of care for the neoadjuvant treatment of resectable, borderline or locally advanced PDAC. Recently the standard of care in the metastatic setting has been improved by the FOLFIRINOX protocol [12], a combination of 5-fluorouracil (5-FU), leucovorin, irinotecan and oxaliplatin that was first examined in colorectal cancer $[13,14]$ and by the combination of gemcitabine plus nanoparticle albumin-bound paclitaxel (nab-paclitaxel) [15]. Both regimens are superior to the standard of single-agent gemcitabine $[12,15]$.

Apart from conventional chemotherapies, various targeted therapies including antiEGFR, anti-VEGF and anti-Her2 antibodies have become the standard of care for certain types of colorectal or gastric cancer [13,16-19]. However, despite numerous large clinical trials, no targeted therapy has as yet demonstrated clinical benefit in PDAC apart from the tyrosine kinase inhibitor erlotinib in combination with gemcitabine [20].

Our understanding of the molecular biology of PDAC increases steadily. Various novel drugs have emerged for a targeted treatment of PDAC. A major focus in PDAC research is nowadays on the interaction of the tumor with its microenvironment, in particular with its surrounding stroma. The tumor stroma with its cellular components, in particular the so-called pancreatic stellate cells, is thought to provide a pro-tumorigenic microenvironment associated with tumor hypoxia, hypovascularization and epithelial-mesenchymal transition. This, in turn, lowers the concentration of chemotherapeutic agents in the tumor and confers chemoresistance, changes the tumor metabolism and leads to the competitive selection of more aggressive tumor subclones [21]. Another concept addresses the marked heterogeneity of PDAC and the likely existence of cancer stem cells or cancer-initiating cells in at least a subset of these tumors. Cancer-initiating cells are characterized by a high level of resistance to common therapies and may be a key factor for tumor recurrence [22]. Again, the stroma appears to play a supportive role since pancreatic stellate cells have been shown to generate a 'niche' for cancer-initiating cells [23].

This review aims at providing an overview on the current and emerging therapeutic strategies in PDAC treatment.

\section{Neoadjuvant Treatment Strategies}

Neoadjuvant treatment in PDAC has different aims. It can be a valid tool for downsizing or even downstaging borderline resectable or locally advanced PDACs and thereby enable surgery with curative intent in a subset of patients. It may also be a strategy to reduce the risk of early metastasis, given the fact that a large proportion of PDACs are likely to be metastatic even when they appear clearly resectable as determined by conventional imaging [24]. 
Various neoadjuvant approaches have been examined for borderline resectable and locally advanced pancreatic cancers, including chemoradiation (CRT), chemotherapy followed by chemotherapy/radiotherapy or intensified chemotherapy. These approaches were largely hampered by the fact that until recently there were few protocols that induced a significant tumor response in a significant number of patients. Only the combination of gemcitabine with oxaliplatin showed a significantly improved response rate compared to gemcitabine alone in a GERCOT trial (26.8 vs. $17.3 \%, \mathrm{p}=0.04$ ), but resectability was not systematically evaluated in these patients. It has become evident that conventional imaging may not be sufficient to assess resectability after neoadjuvant treatment and therefore even patients who exhibit stable disease according to computed tomography or magnetic resonance imaging after neoadjuvant treatment should undergo diagnostic laparotomy to evaluate resectability [25]. Recently, there have been small trials publishing promising data for the use of FOLFIRINOX [26] or gemcitabine plus nab-paclitaxel $[10,27]$, but these data have to be confirmed in larger, randomized trials.

There have been conflicting data regarding the use of CRT with either gemcitabine or fluoropyrimidines [28] in patients with locally advanced PDAC [29-32]. This is mainly due to the fact that while local recurrence can be controlled by CRT, the majority of patients succumb to distal metastases. Retrospective analyses suggested that a strategy with initial chemotherapy followed by CRT for those patients who had at least stable disease during chemotherapy may help to select those patients who really benefit from the addition of radiotherapy as local treatment. However, when this hypothesis was examined in a prospective trial (the so-called LAP-07 trial), there was no difference in OS of patients with locally advanced PDAC receiving gemcitabine followed by CRT with capecitabine as compared to gemcitabine only treatment [33]. Given these data, CRT in locally advanced PDAC should only be performed within a clinical trial.

Data on combinations of CRT with targeted therapies are still preliminary. A recently published phase II trial reported no benefit for the addition of bevacizumab to a capecitabinebased CRT followed by gemcitabine [34]. Interesting survival rates (1-year OS 66\%, 2-year OS $25 \%$ ) were reported in a single-arm phase II trial using a combination of cetuximab, gemcitabine and oxaliplatin followed by CRT with cetuximab/capecitabine in locally advanced pancreatic cancer, with acceptable toxicity [35]. The above-mentioned LAP-07 trial also examined the use of adding erlotinib to gemcitabine for the treatment of patients with locally advanced PDAC. However, the addition of erlotinib did not confer any benefit [33].

New approaches with the aim of finally defining the role of neoadjuvant therapies in resectable, borderline and locally advanced disease are currently under investigation by many study groups. In particular, there is increasing interest in true neoadjuvant treatment concepts to improve the outcome of patients with clearly resectable disease.

\section{Adjuvant Treatment}

PDAC is characterized by its high risk of early metastasis. This fact and the chance of minimal residual disease after resection are the rationale of adjuvant chemotherapy. Three major trials could confirm a survival benefit for adjuvant chemotherapy with gemcitabine or 5-FU after R0/R1 resection compared to surgery alone [36-38]. Based on these and further studies there are general recommendations for adjuvant therapy (table 1, fig. 1). The ESPAC-1 trial compared chemotherapy with 5-FU/leucovorin (CT) versus CRT or observation (0). This trial used a $2 \times 2$ factorial design and showed significant differences in favor of CT in median progression-free survival (mPFS) (15.3 months CT vs. 9.4 months $0, p=0.02$; 10.7 months CRT vs. 15.2 months no CRT, $\mathrm{p}=0.04)$ and median OS (mOS) (20.1 months CT 


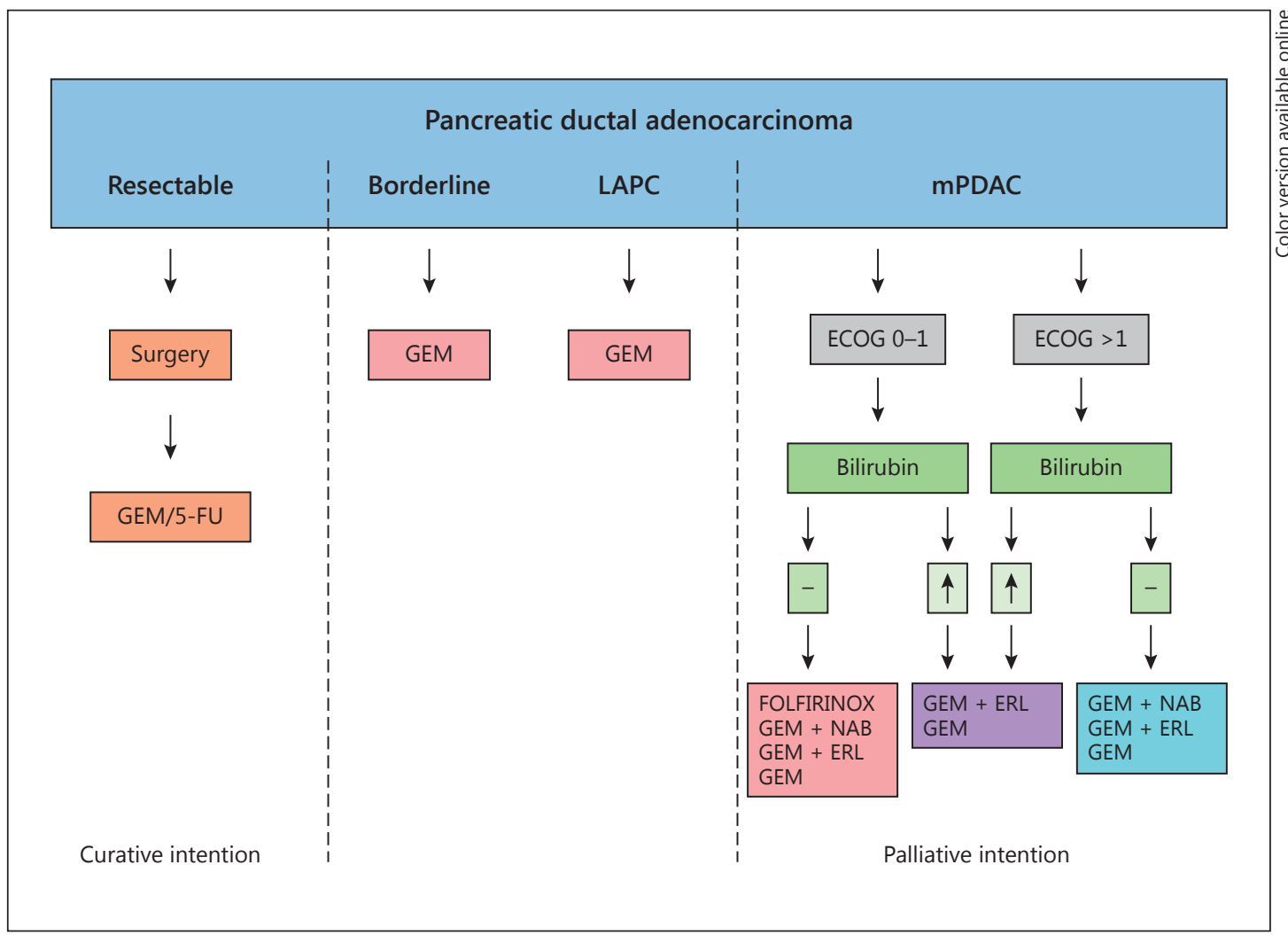

Fig. 1. Stage-dependent therapeutic decisions in pancreatic cancer. $E R L=$ Erlotinib; GEM = gemcitabine; LAPC = locally advanced pancreatic cancer; $\mathrm{mPDAC}=$ metastatic PDAC; NAB = nab-paclitaxel; - = normal; $\uparrow=$ bilirubin $>1.5$ times the upper limit of normal.

Table 1. Adjuvant therapies in PDAC

\begin{tabular}{|c|c|c|c|c|c|c|c|c|c|}
\hline Trial & Treatment & $\begin{array}{l}\text { Patients, } \\
\mathrm{n}\end{array}$ & $\begin{array}{l}\text { mPFS, } \\
\text { months }\end{array}$ & $\begin{array}{l}\mathrm{p} \\
\text { value }\end{array}$ & $\begin{array}{l}\text { mOS, } \\
\text { months }\end{array}$ & $\begin{array}{l}\mathrm{p} \\
\text { value }\end{array}$ & $\begin{array}{l}\text { 2-year } \\
\text { OS, \% }\end{array}$ & $\begin{array}{l}5 \text {-year } \\
\text { OS, \% }\end{array}$ & Ref \\
\hline EORTC & $\begin{array}{l}\text { observation } \\
\text { 5-FU/RT }\end{array}$ & $\begin{array}{l}108 \\
110\end{array}$ & $\begin{array}{l}16.0 \\
17.4\end{array}$ & NR & $\begin{array}{l}19.0 \\
24.5\end{array}$ & 0.208 & $\begin{array}{l}41 \\
51\end{array}$ & $\begin{array}{l}22 \\
28\end{array}$ & 72 \\
\hline ESPAC-1 & $\begin{array}{l}\text { CRT vs. no } \mathrm{CRT}^{1} \\
\text { CTx vs. no CTx }\end{array}$ & $\begin{array}{l}145 / 144 \\
147 / 142\end{array}$ & $\begin{array}{l}10.7 / 15.2 \\
15.3 / 9.4\end{array}$ & $\begin{array}{l}0.04 \\
0.02\end{array}$ & $\begin{array}{l}15.9 / 17.9 \\
20.1 / 15.5\end{array}$ & $\begin{array}{l}0.05 \\
0.009\end{array}$ & $\begin{array}{l}29 / 41 \\
40 / 30\end{array}$ & $\begin{array}{l}10 / 20 \\
21 / 8\end{array}$ & 38 \\
\hline CONKO-001 & $\begin{array}{l}\text { observation } \\
\text { gemcitabine }\end{array}$ & $\begin{array}{l}175 \\
179\end{array}$ & $\begin{array}{r}6.7 \\
13.4\end{array}$ & $<0.001$ & $\begin{array}{l}20.2 \\
22.8\end{array}$ & 0.01 & NR & $\begin{array}{l}10.4 \\
20.7\end{array}$ & 37 \\
\hline ESPAC-3 & $\begin{array}{l}\text { 5-FU/LV } \\
\text { gemcitabine }\end{array}$ & $\begin{array}{l}551 \\
537\end{array}$ & $\begin{array}{l}14.1 \\
14.3\end{array}$ & 0.53 & $\begin{array}{l}23.0 \\
23.6\end{array}$ & 0.39 & $\begin{array}{l}48.1 \\
49.1\end{array}$ & NR & 36 \\
\hline RTOG 9704 & $\begin{array}{l}\text { 5-FU/RT } \\
\text { gemcitabine/RT }\end{array}$ & $\begin{array}{l}230 \\
221\end{array}$ & NR & NR & $\begin{array}{l}17.1 \\
20.5\end{array}$ & 0.08 & NR & $\begin{array}{l}18 \\
22\end{array}$ & 73 \\
\hline JASPAC-01 & $\begin{array}{l}\text { S-1 } \\
\text { gemcitabine }\end{array}$ & $\begin{array}{l}187 \\
191\end{array}$ & $\begin{array}{l}23.3 \\
11.2\end{array}$ & 0.67 & $\begin{array}{l}46.3 \\
25.9\end{array}$ & $<0.001$ & $\begin{array}{l}70 \\
53\end{array}$ & NR & 41 \\
\hline
\end{tabular}

CONKO = Charité Onkologie; CTx = chemotherapy with 5-FU and leucovorin; EORTC = European Organisation for Research and Treatment of Cancer; ESPAC = European Study Group for Pancreatic Cancer; JASPAC = Japan Adjuvant Study Group of Pancreatic Cancer; LV = leucovorin; NR = not reported; Ref. = reference; $\mathrm{RT}$ = radiotherapy; RTOG = Radiation Therapy Oncology Group.

${ }^{1} \mathrm{CRT}=5-\mathrm{FU} /$ leucovorin + radiotherapy. 
vs. 15.5 months $0, \mathrm{p}=0.009 ; 15.9$ months CRT vs. 17.9 months no CRT, $\mathrm{p}=0.05$ ) as well as 5 -year OS rates (21\% CT vs. $10 \%$ CRT vs. $8 \%$ 0) [38]. The CONKO-001 compared gemcitabine with best supportive care after R0/R1 resection of PDAC. This trial also showed a significant benefit in favor of chemotherapy with respect to mPFS (13.4 vs. 6.7 months, $\mathrm{p}<0.001)$ and mOS (22.8 vs. 20.2 months, $p=0.01$ ) as well as 5-year OS rates (20.7 vs. $10.4 \%$ ) [37]. The ESPAC-3 trial directly compared both regimens (5-FU and gemcitabine) and did not show a significant difference in outcome, but differences in the respective toxicity profiles [36]. Accordingly both substances are recommended equally for adjuvant treatment and can replace each other.

\section{When to Start Adjuvant Treatment?}

It is currently unclear when adjuvant chemotherapy should be started after surgery for pancreatic cancer. In other tumor entities such as colorectal cancer, starting as early as possible after surgery has been recommended to obtain the maximum benefit from this treatment [39]. After surgery for pancreatic cancer the start of adjuvant chemotherapy is frequently delayed due to postoperative complications or slow recovery of the patient. A recently published subgroup analysis of the ESPAC-3 trial suggests that the treatment duration (6 months) and the associated dose intensity are more relevant than a very early (within 6 weeks) initiation of treatment after surgery. Indeed, there was no significant difference in OS when chemotherapy was started up to 12 weeks after surgery [40].

\section{Novel Drugs in the Adjuvant Setting}

A promising new drug for adjuvant therapy of PDAC may be S-1, an oral fluoropyrimidine. The recently presented data of the JASPAC-01 trial revealed a significantly superior 2-year OS rate for S-1 compared to gemcitabine (70 vs. 53\%) [41]. However, the trial is not yet fully published and is limited to an Asian collective and will have to be reproduced in the Caucasian population due to differences in the metabolism of S-1 between Asian and Caucasian patients. Further new concepts examine FOLFIRINOX or nab-paclitaxel/gemcitabine compared with single-agent gemcitabine in the adjuvant setting $[42,43]$.

\section{Metastatic Pancreatic Cancer}

Most patients with pancreatic cancer present with metastatic disease. At this stage systemic chemotherapy is the mainstay of therapy. There is a relationship between the patient's performance status and the therapeutic outcome in first- and second-line therapy of advanced PDAC [44-46]. Chemotherapy should not be applied above an Eastern Cooperative Oncology Group (ECOG) score of 2.

\section{First-Line Therapy}

Gemcitabine and the combination of gemcitabine/erlotinib have been the standard of care for quite some time [20,47]. Erlotinib is a selective, small-molecule inhibitor of the EGFR tyrosine kinase and so far the only approved targeted therapy in PDAC. The addition of erlotinib to gemcitabine improved the mOS of patients in a phase III study by 0.33 months (about 10 days) in the experimental arm, which was statistically significant but of questionable clinical relevance [20]. However, according to an as yet not fully published subgroup analysis, patients who developed skin rash upon erlotinib treatment did benefit from the combination (mOS up to 10.5 months), whereas patients without skin rash had no benefit from additional erlotinib. Consequently, discontinuation of erlotinib is recommended in case no rash appears within the first 8 weeks of treatment with erlotinib. Another EGFR inhibitor, cetuximab, was 
also examined and did not show a significant difference in mOS. There is no subgroup analysis for skin rash for that trial [48]. Further trials are required to precisely define the patient population that benefits from a combinational approach, since other EGFR inhibitors like panitumumab (phase II) [49], nimotuzumab (phase II) [50] and matuzumab (phase I) [51] showed promising effects, but have not been tested in a phase III setting.

After a long series of failed phase III trials, the FOLFIRINOX protocol (5-FU/leucovorin/irinotecan/oxaliplatin) substantially improved all outcome parameters in metastatic PDAC compared to gemcitabine alone: response rate (54 vs. 16\%, p < 0.001), mPFS (6.4 vs. 3.3 months, $\mathrm{HR}=0.47$ ) and mOS (11.1 vs. 6.8 months, $\mathrm{HR}=0.57)$. The OS rate at 1 year was $48.4 \%$ for FOLFIRINOX and $20.6 \%$ for gemcitabine, respectively [12]. FOLFIRINOX is more toxic than gemcitabine. There are significantly more neutropenia and consecutive febrile neutropenia as well as non-hematological adverse effects such as sensory neuropathy. Interestingly, a subgroup analysis of the PRODIGE 4/ACCORD 11 trial revealed an improved quality of life for FOLFIRINOX compared to gemcitabine despite the increased toxicity of this regimen [52].

The second combination regimen that was superior to single-agent gemcitabine is the recently published combination of nab-paclitaxel with gemcitabine. The combination was superior with respect to PFS (5.5 vs. 3.7 months, HR = 0.69) and OS (8.5 vs. 6.7 months, HR = 0.72 ) [15]. The 1 -year OS rate was $35 \%$ for the combination and $22 \%$ for gemcitabine monotherapy. The trial included only patients with normal bilirubin levels. The combination of gemcitabine and nab-paclitaxel conferred more side effects than gemcitabine, in particular with respect to hematotoxicity and neurotoxicity. However, severe side effects such as febrile neutropenia were less frequent than in the ACCORD trial with FOLFIRINOX. The more favorable toxicity profile makes the combination of nab-paclitaxel and gemcitabine the preferred new chemotherapy backbone for novel combinations. More than 30 trials are currently listed in Clinical Trials that use this backbone together with a novel, mostly targeted therapeutic agent for PDAC.

The combination of nab-paclitaxel with gemcitabine is the only gemcitabine-based combination that significantly increases OS compared to gemcitabine monotherapy. The conjugation of paclitaxel with albumin nanoparticles as a carrier protein may improve its effectiveness by using albumin as a natural carrier for hydrophobic molecules and its active, gp60 receptor-mediated transcytosis across the blood vessel endothelium. Another possible explanation for the efficacy of this combination regimen are synergisms between both substances. In a preclinical mouse model nab-paclitaxel reduced the activity of cytidine deaminase, the key enzyme for inactivation of gemcitabine that is overexpressed in human PDAC [53]. Moreover, nab-paclitaxel interacts with the tumor-surrounding stroma. Preclinical data using human PDAC cell lines and samples show a reduction in stromal density after treatment with nab-paclitaxel/gemcitabine $[54,55]$. The reduced stromal density goes along with increased vascularity, which may facilitate gemcitabine delivery and lead to a higher intratumoral gemcitabine concentration [54].

The availability of four different regimens for metastatic PDAC enables us now, for the first time, to tailor the treatment to the individual patient. Patients with metastatic PDAC younger than 75 years, with a good performance status (ECOG score of 0-1) and bilirubin levels $\leq 1.5$ times the upper limit of normal qualify for FOLFIRINOX (since these were the inclusion criteria for the study) [12]. According to the data of the MPACT trial, the combination of nab-paclitaxel and gemcitabine is also feasible in patients older than 75 years and with an ECOG score of 0-2, but with normal bilirubin levels. In a subgroup analysis, patients with highly increased CA19-9 levels did particularly benefit from this combination. Patients not fulfilling these criteria are still eligible for gemcitabine or the combination of gemcitabine with erlotinib. 
Tumors

Table 2. Second-line therapies in advanced PDAC

\begin{tabular}{|c|c|c|c|c|c|c|c|}
\hline Regimen & Phase & $\begin{array}{l}\text { Patients, } \\
\mathrm{n}\end{array}$ & $\begin{array}{l}\text { mPFS, } \\
\text { months }\end{array}$ & $\begin{array}{l}\text { mos, } \\
\text { months }\end{array}$ & $\begin{array}{l}\text { 6-month } \\
\text { OS, \% }\end{array}$ & $\begin{array}{l}\text { DCR, } \\
\%\end{array}$ & Ref. \\
\hline FOLFIRINOX & ret. & 22 & 5.4 & 8.5 & n.a. & 63 & 58 \\
\hline FOLFIRINOX & ret. & 18 & 2.8 & 8.4 & 44.4 & 55.6 & 74 \\
\hline Nab-paclitaxel & II & 19 & 1.7 & 7.3 & 58 & 37 & 59 \\
\hline FOLFIRI & II & 50 & 3.2 & 5.0 & 32 & 36 & 75 \\
\hline Capecitabine/docetaxel & II & 43 & 3.7 & 5.3 & n.a. & 73 & 76 \\
\hline $\begin{array}{l}\text { Modified FOLFOX } \\
\text { FOLFIRI }\end{array}$ & II & $\begin{array}{l}30 \\
31\end{array}$ & $\begin{array}{l}1.5 \\
2.1\end{array}$ & $\begin{array}{l}3.7 \\
4.2\end{array}$ & $\begin{array}{l}30 \\
27\end{array}$ & $\begin{array}{l}17 \\
23\end{array}$ & 77 \\
\hline $\mathrm{OFF}$ & III & 46 & & 4.8 & n.a. & n.a. & 56 \\
\hline Mitomycin/ifosfamide & II & 21 & 1.7 & 3.7 & n.a. & 15 & 78 \\
\hline Capecitabine/oxaliplatin & II & 39 & 2.5 & 5.8 & 44 & 28.6 & 79 \\
\hline $\begin{array}{l}\text { OFF } \\
\text { FF }\end{array}$ & III & $\begin{array}{l}76 \\
84\end{array}$ & $\begin{array}{l}2.9 \\
2.0\end{array}$ & $\begin{array}{l}5.9 \\
3.3\end{array}$ & n.a. & n.a. & 57 \\
\hline Nal-IRI & II & 40 & 2.4 & 5.2 & 42.5 & 50 & 62 \\
\hline $\begin{array}{l}\text { Nal-IRI/5-FU/LV } \\
\text { 5-FU/LV }\end{array}$ & III & 417 & $\begin{array}{l}3.1 \\
1.5\end{array}$ & $\begin{array}{l}6.1 \\
4.2\end{array}$ & n.a. & n.a. & 63 \\
\hline Gemcitabine/oxaliplatin & II & 33 & 4.2 & 6 & n.a. & 61.3 & 80 \\
\hline Vatalanib & II & 67 & 2 & n.a. & 29 & 31 & 81 \\
\hline 5-FU/paclitaxel & II & 28 & 2.5 & 7.6 & n.a. & 30 & 82 \\
\hline FOLFOX & II & 44 & 2.5 & 7.8 & n.a. & 40.9 & 83 \\
\hline
\end{tabular}

DCR = Disease control rate; FF = folinic acid and 5-FU; FOLFIRI = 5-FU, leucovorin and irinotecan; FOLFOX = 5-FU, leucovorin and oxaliplatin; LV = leucovorin; n.a. = not assessed; Ref. = reference; ret. = retrospective.

\section{Second-Line Therapy}

For a long time second-line therapy in pancreatic cancer was uncommon. However, recent data showed that the combination of 5-FU/leucovorin and oxaliplatin (OFF) significantly prolongs OS by 2.52 months compared to best supportive care $(p=0.008)$ [56]. This regimen can be recommended for patients with an ECOG score of 0-2 [57]. Second-line therapy with gemcitabine can be beneficial for patients who were previously treated with FOLFIRINOX [12]. There are also data from small prospective or retrospective trials using the FOLFIRINOX protocol [58] or nab-paclitaxel [59] as monotherapy in the second-line setting. Table 2 gives an overview on various second-line trials in metastatic PDAC. In summary, the data demonstrate a mPFS of 3 months and a mOS of up to 6 months for second-line treatments. This shows that patients with advanced pancreatic cancer eligible to receive secondline treatment substantially benefit from such therapy.

Improved conjugation systems may also offer a chance to improve the efficacy of chemotherapeutics for second-line treatment. The formulation of nanoliposomal irinotecan (nalIRI) yielded increased intratumoral levels of CPT-11 and its active metabolite SN-38 compared to standard irinotecan in a mouse xenograft of human colon carcinoma and pancreatic cancer $[60,61]$. The preclinical data could be somewhat confirmed by a phase II and III study of 
nal-IRI in advanced gemcitabine-refractory PDAC $[62,63]$. After failure of first-line therapy with gemcitabine, nal-IRI treatment achieved a mPFS of 2.4 months and a mOS of 5.2 months, with a disease control rate of $50 \%$ in the phase II trial [62]. These data were confirmed by the so far not fully published NAPOLI-1 trial (phase III) [63]. Here the combination of nal-IRI with 5 -FU/leucovorin significantly improved mPFS (3.1 vs. 1.5 months, HR $=0.56$ ) and mOS (6.1 vs. 4.2 months, $\mathrm{HR}=0.67$ ) compared to 5 -FU/leucovorin. Nal-IRI as a single agent was not significantly superior to 5-FU/leucovorin. However, the combination of nal-IRI with 5-FU/leucovorin has side effects such as fatigue and diarrhea that need to be considered in this setting, see figure 1 .

Even at the early stages of tumor development, local and systemic inflammation is present in PDAC $[64,65]$. Given the role of JAK/STAT signaling in this setting, the combination of the JAK1/2 inhibitor ruxolitinib with capecitabine was recently compared to capecitabine plus placebo in a phase II trial in the second-line setting [66]. Within the randomized population, $\mathrm{mPFS}(\mathrm{HR}=0.75)$ and mOS $(\mathrm{HR}=0.79)$ favored ruxolitinib over placebo. Interestingly, the subgroup with elevated CRP levels ( $>13 \mathrm{mg} / \mathrm{l}$ ) significantly benefited from the addition of ruxolitinib compared to capecitabine monotherapy (3- and 6-month OS rates 48 and $42 \%$ vs. 29 and 11\%) [66].

\section{Immunotherapy for PDAC?}

Cytotoxic T-lymphocyte-associated antigen 4 (CTLA-4) is a pivotal immune-inhibitory molecule [67]. In a mouse model of two non-immunogenic murine tumor models, the combination of a CTLA-4 inhibitor and gemcitabine was tested. The combination exhibited tumor regression and long-term protective immunity, indicating a synergistic effect in the treatment of cancer [68]. In a first clinical trial, monotherapy with the CTLA-4 inhibitor ipilimumab failed to show a significant benefit in locally advanced or metastatic PDAC [69].

Another approach for specific targeting of participating tumor-associated antigens are vaccination strategies. In a recent phase II trial a vaccine of devitalized allogeneic pancreatic cancer cells transfected with GM-CSF (GVAX) was combined with mesothelin-expressing liveattenuated Listeria monocytogenes (CRS-207) for additive stimulation of the innate and adaptive immunity and compared to GVAX alone [70]. Prior to GVAX patients received low-dose cyclophosphamide as an immune modulator for inhibition of regulatory T cells. The trial was conducted in a patient collective with metastatic PDAC and at least one prior chemotherapy regimen. An interim analysis of 90 patients revealed a significantly improved OS for the combination of GVAX plus CRS-207 in contrast to GVAX alone (mOS 6.1 vs. 3.9 months, $\mathrm{HR}=0.54$ ] [70]. A phase IIb trial (ECLIPSE) is currently examining this concept in patients with pretreated metastatic PDAC [71].

\section{Conclusion}

FOLFIRINOX and nab-paclitaxel/gemcitabine have improved the standard of care for patients with metastatic PDAC. These combinations may also improve the treatment of PDAC in the neoadjuvant and adjuvant setting. Nab-paclitaxel plus gemcitabine is a novel backbone for the development of further therapeutic regimens in locally advanced and metastatic PDAC.

Since PDAC is a heterogeneous and genetically highly complex disease, the molecular characterization of a given tumor represents an important cornerstone for the development of future therapies. To overcome the difficulties associated with intratumoral heterogeneity 
of PDAC, various targets in different pathways have to be considered. However, the first experiences with such multi-targeting strategies resulted in increased toxicity as a limiting factor. A major challenge is also the establishment of biomarkers in the tumor and/or in blood (liquid biopsies) for response prediction, response evaluation and molecular monitoring of the tumor under or after therapy.

\section{References}

1 Jemal A, Siegel R, Xu J, Ward E: Cancer statistics, 2010. CA Cancer J Clin 2010;60:277-300.

2 Howlader N, Noone AM, Krapcho M, Garshell J, Miller D, Altekruse SF, Kosary CL, Yu M, Ruhl J, Tatalovich Z, Mariotto A, Lewis DR, Chen HS, Feuer EJ, Cronin KA (eds): SEER Cancer Statistics Review (CSR) 1975-2011. National Cancer Institute 2014. http://seer.cancer.gov/csr/1975_2011/ (accessed 2014).

3 Rahib L, Smith BD, Aizenberg R, Rosenzweig AB, Fleshman JM, Matrisian LM: Projecting cancer incidence and deaths to 2030: the unexpected burden of thyroid, liver, and pancreas cancers in the United States. Cancer Res 2014;74:2913-2921.

4 Haberland J, Bertz J, Wolf U, Ziese T, Kurth BM: German cancer statistics 2004. BMC Cancer 2010;10:52.

5 Palmer DH, Stocken DD, Hewitt H, Markham CE, Hassan AB, Johnson PJ, Buckels JA, Bramhall SR: A randomized phase 2 trial of neoadjuvant chemotherapy in resectable pancreatic cancer: gemcitabine alone versus gemcitabine combined with cisplatin. Ann Surg Oncol 2007;14:2088-2096.

6 Heinrich S, Pestalozzi BC, Schafer M, Weber A, Bauerfeind P, Knuth A, Clavien PA: Prospective phase II trial of neoadjuvant chemotherapy with gemcitabine and cisplatin for resectable adenocarcinoma of the pancreatic head. J Clin Oncol 2008;26:2526-2531.

7 Evans DB, Varadhachary GR, Crane CH, Sun CC, Lee JE, Pisters PW, Vauthey JN, Wang H, Cleary KR, Staerkel GA, Charnsangavej C, Lano EA, Ho L, Lenzi R, Abbruzzese JL, Wolff RA: Preoperative gemcitabine-based chemoradiation for patients with resectable adenocarcinoma of the pancreatic head. J Clin Oncol 2008;26:34963502.

8 Varadhachary GR, Wolff RA, Crane CH, Sun CC, Lee JE, Pisters PW, Vauthey JN, Abdalla E, Wang H, Staerkel GA, Lee JH, Ross WA, Tamm EP, Bhosale PR, Krishnan S, Das P, Ho L, Xiong H, Abbruzzese JL, Evans DB: Preoperative gemcitabine and cisplatin followed by gemcitabine-based chemoradiation for resectable adenocarcinoma of the pancreatic head. J Clin Oncol 2008;26:3487-3495.

9 Pisters PW, Wolff RA, Janjan NA, Cleary KR, Charnsangavej C, Crane CN, Lenzi R, Vauthey JN, Lee JE, Abbruzzese JL, Evans DB: Preoperative paclitaxel and concurrent rapid-fractionation radiation for resectable pancreatic adenocarcinoma: toxicities, histologic response rates, and event-free outcome. J Clin Oncol 2002;20:25372544.

10 Kunzmann V, Hartlapp I, Scheurlen M, Einsele H, Mueller J, Kenn W, Steger U, Germer CT: Sequential neoadjuvant chemotherapy with nab-paclitaxel plus gemcitabine and FOLFIRINOX in locally advanced pancreatic cancer (LAPC): a pilot study. J Clin Oncol 2013;31(suppl):abstr e15193.

11 Vasile E, De Lio N, Cappelli C, Pollina L, Funel N, Sainato A, Ginocchi L, Lucchesi M, Caparello C, Caponi S, Perrone V, Pasqualetti F, Caniglia F, Signori S, Mazzeo S, Greco C, Falcone A, Campani D, Mosca F, Boggi U: Phase II study of neoadjuvant chemotherapy with modified FOLFOXIRI in borderline resectable or unresectable stage III pancreatic cancer. J Clin Oncol 2013;31(suppl):abstr 4062.

12 Conroy T, Desseigne F, Ychou M, Bouche O, Guimbaud R, Becouarn Y, Adenis A, Raoul JL, Gourgou-Bourgade S, de la Fouchardiere C, Bennouna J, Bachet JB, Khemissa-Akouz F, Pere-Verge D, Delbaldo C, Assenat E, Chauffert B, Michel P, Montoto-Grillot C, Ducreux M: FOLFIRINOX versus gemcitabine for metastatic pancreatic cancer. N Engl J Med 2011;364:1817-1825.

13 Assenat E, Desseigne F, Thezenas S, Viret F, Mineur L, Kramar A, Samalin E, Portales F, Bibeau F, Crapez-Lopez E, Bleuse JP, Ychou M: Cetuximab plus FOLFIRINOX (ERBIRINOX) as first-line treatment for unresectable metastatic colorectal cancer: a phase II trial. Oncologist 2011;16:1557-1564.

14 Ychou M, Viret F, Kramar A, Desseigne F, Mitry E, Guimbaud R, Delpero JR, Rivoire M, Quenet F, Portier G, Nordlinger B: Tritherapy with fluorouracil/leucovorin, irinotecan and oxaliplatin (FOLFIRINOX): a phase II study in colorectal cancer patients with non-resectable liver metastases. Cancer Chemother Pharmacol 2008; 62:195-201.

15 Von Hoff DD, Ervin T, Arena FP, Chiorean EG, Infante J, Moore M, Seay T, Tjulandin SA, Ma WW, Saleh MN, Harris M, Reni M, Dowden S, Laheru D, Bahary N, Ramanathan RK, Tabernero J, Hidalgo M, Goldstein D, Van Cutsem E, Wei X, Iglesias J, Renschler MF: Increased survival in pancreatic cancer with nab-paclitaxel plus gemcitabine. N Engl J Med 2013;369:1691-1703.

16 Douillard JY, Siena S, Cassidy J, Tabernero J, Burkes R, Barugel M, Humblet Y, Bodoky G, Cunningham D, Jassem J, Rivera F, Kocakova I, Ruff P, Blasinska-Morawiec M, Smakal M, Canon JL, Rother M, Oliner KS, Wolf M, Gansert J: Randomized, phase III trial of panitumumab with infusional fluorouracil, leucovorin, and oxaliplatin (FOLFOX4) versus FOLFOX4 alone as first-line treatment in patients with previously untreated metastatic colorectal cancer: the PRIME study. J Clin Oncol 2010;28:4697-4705. 
Giantonio BJ, Catalano PJ, Meropol NJ, O’Dwyer PJ, Mitchell EP, Alberts SR, Schwartz MA, Benson AB 3rd: Bevacizumab in combination with oxaliplatin, fluorouracil, and leucovorin (FOLFOX4) for previously treated metastatic colorectal cancer: results from the Eastern Cooperative Oncology Group Study E3200. J Clin Oncol 2007; 25:1539-1544.

18 Van Cutsem E, Kohne CH, Hitre E, Zaluski J, Chang Chien CR, Makhson A, D’Haens G, Pinter T, Lim R, Bodoky G, Roh JK, Folprecht G, Ruff P, Stroh C, Tejpar S, Schlichting M, Nippgen J, Rougier P: Cetuximab and chemotherapy as initial treatment for metastatic colorectal cancer. N Engl J Med 2009;360:1408-1417.

19 Wilke H, Muro K, Van Cutsem E, Oh SC, Bodoky G, Shimada Y, Hironaka S, Sugimoto N, Lipatov O, Kim TY, Cunningham D, Rougier P, Komatsu Y, Ajani J, Emig M, Carlesi R, Ferry D, Chandrawansa K, Schwartz JD, Ohtsu A: Ramucirumab plus paclitaxel versus placebo plus paclitaxel in patients with previously treated advanced gastric or gastro-oesophageal junction adenocarcinoma (RAINBOW): a double-blind, randomised phase 3 trial. Lancet Oncol 2014;15:1224-1235.

20 Moore MJ, Goldstein D, Hamm J, Figer A, Hecht JR, Gallinger S, Au HJ, Murawa P, Walde D, Wolff RA, Campos D, Lim R, Ding K, Clark G, Voskoglou-Nomikos T, Ptasynski M, Parulekar W: Erlotinib plus gemcitabine compared with gemcitabine alone in patients with advanced pancreatic cancer: a phase III trial of the National Cancer Institute of Canada Clinical Trials Group. J Clin Oncol 2007;25:1960-1966.

21 Erkan M, Reiser-Erkan C, Michalski CW, Deucker S, Sauliunaite D, Streit S, Esposito I, Friess H, Kleeff J: Cancerstellate cell interactions perpetuate the hypoxia-fibrosis cycle in pancreatic ductal adenocarcinoma. Neoplasia 2009;11:497-508.

22 Lonardo E, Frias-Aldeguer J, Hermann PC, Heeschen C: Pancreatic stellate cells form a niche for cancer stem cells and promote their self-renewal and invasiveness. Cell Cycle 2012;11:1282-1290.

23 Lonardo E, Hermann PC, Mueller MT, Huber S, Balic A, Miranda-Lorenzo I, Zagorac S, Alcala S, RodriguezArabaolaza I, Ramirez JC, Torres-Ruiz R, Garcia E, Hidalgo M, Cebrian DA, Heuchel R, Lohr M, Berger F, Bartenstein P, Aicher A, Heeschen C: Nodal/Activin signaling drives self-renewal and tumorigenicity of pancreatic cancer stem cells and provides a target for combined drug therapy. Cell Stem Cell 2011;9:433-446.

24 Haeno H, Gonen M, Davis MB, Herman JM, Iacobuzio-Donahue CA, Michor F: Computational modeling of pancreatic cancer reveals kinetics of metastasis suggesting optimum treatment strategies. Cell 2012;148: 362-375.

25 Stefanidis D, Grove KD, Schwesinger WH, Thomas CR Jr: The current role of staging laparoscopy for adenocarcinoma of the pancreas: a review. Ann Oncol 2006;17:189-199.

26 Hosein PJ, Macintyre J, Kawamura C, Maldonado JC, Ernani V, Loaiza-Bonilla A, Narayanan G, Ribeiro A, Portelance L, Merchan JR, Levi JU, Rocha-Lima CM: A retrospective study of neoadjuvant FOLFIRINOX in unresectable or borderline-resectable locally advanced pancreatic adenocarcinoma. BMC Cancer 2012;12:199.

27 MacKenzie S, Zeh H, McCahill LE, Sielaff TD, Bahary N, Gribbin TE, Seng JE, Leach JW, Harmon J, Demeure MJ, Von Hoff JD, Moser AJ, Ramanathan RK: A pilot phase II multicenter study of nab-paclitaxel (Nab-P) and gemcitabine (G) as preoperative therapy for potentially resectable pancreatic cancer (PC). J Clin Oncol 2013; 31(suppl):abstr 4038.

28 Mukherjee S, Hurt CN, Bridgewater J, Falk S, Cummins S, Wasan H, Crosby T, Jephcott C, Roy R, Radhakrishna G, McDonald A, Ray R, Joseph G, Staffurth J, Abrams RA, Griffiths G, Maughan T: Gemcitabine-based or capecitabine-based chemoradiotherapy for locally advanced pancreatic cancer (SCALOP): a multicentre, randomised, phase 2 trial. Lancet Oncol 2013;14:317-326.

29 Barhoumi M, Mornex F, Bonnetain F, Rougier P, Mariette C, Bouche O, Bosset JF, Aparicio T, Mineur L, Azzedine A, Hammel P, Butel J, Stremsdoerfer N, Maingon P, Bedenne L, Chauffert B: Locally advanced unresectable pancreatic cancer: induction chemoradiotherapy followed by maintenance gemcitabine versus gemcitabine alone: definitive results of the 2000-2001 FFCD/SFRO phase III trial (in French). Cancer Radiother 2011;15:182-191.

30 Chauffert B, Mornex F, Bonnetain F, Rougier P, Mariette C, Bouche O, Bosset JF, Aparicio T, Mineur L, Azzedine A, Hammel P, Butel J, Stremsdoerfer N, Maingon P, Bedenne L: Phase III trial comparing intensive induction chemoradiotherapy (60 Gy, infusional 5-FU and intermittent cisplatin) followed by maintenance gemcitabine with gemcitabine alone for locally advanced unresectable pancreatic cancer. Definitive results of the 2000-01 FFCD/SFRO study. Ann Oncol 2008;19:1592-1599.

31 Loehrer PJ Sr, Feng Y, Cardenes H, Wagner L, Brell JM, Cella D, Flynn P, Ramanathan RK, Crane CH, Alberts SR, Benson AB 3rd: Gemcitabine alone versus gemcitabine plus radiotherapy in patients with locally advanced pancreatic cancer: an Eastern Cooperative Oncology Group trial. J Clin Oncol 2011;29:4105-4112.

32 Huguet F, Andre T, Hammel P, Artru P, Balosso J, Selle F, Deniaud-Alexandre E, Ruszniewski P, Touboul E, Labianca R, de Gramont A, Louvet C: Impact of chemoradiotherapy after disease control with chemotherapy in locally advanced pancreatic adenocarcinoma in GERCOR phase II and III studies. J Clin Oncol 2007;25:326331.

33 Hammel P, Huguet F, Van Laethem JL, Goldstein D, Glimelius B, Artru P, Borbath I, Bouche O, Shannon J, André T, Mineur L, Chibaudel B, Bonnetain F, Louvet C: Comparison of chemoradiotherapy and chemotherapy in patients with a locally advanced pancreatic cancer controlled after 4 months of gemcitabine with or without erlotinib: Final results of the international phase III LAP 07 study. Chicago, American Society of Clinical Oncology Annual Meeting, May 31 to June 4 2013, abstr LBA4003.

34 Small W Jr, Mulcahy MF, Rademaker A, Bentrem DJ, Benson AB, Weitner BB, Talamonti MS: Phase II trial of full-dose gemcitabine and bevacizumab in combination with attenuated three-dimensional conformal radiotherapy in patients with localized pancreatic cancer. Int J Radiat Oncol Biol Phys 2011;80:476-482. 
35 Crane CH, Varadhachary GR, Yordy JS, Staerkel GA, Javle MM, Safran H, Haque W, Hobbs BD, Krishnan S, Fleming JB, Das P, Lee JE, Abbruzzese JL, Wolff RA: Phase II trial of cetuximab, gemcitabine, and oxaliplatin followed by chemoradiation with cetuximab for locally advanced (T4) pancreatic adenocarcinoma: correlation of Smad4(Dpc4) immunostaining with pattern of disease progression. J Clin Oncol 2011;29:3037-3043.

36 Neoptolemos JP, Stocken DD, Bassi C, Ghaneh P, Cunningham D, Goldstein D, Padbury R, Moore MJ, Gallinger S, Mariette C, Wente MN, Izbicki JR, Friess H, Lerch MM, Dervenis C, Olah A, Butturini G, Doi R, Lind PA, Smith D, Valle JW, Palmer DH, Buckels JA, Thompson J, McKay CJ, Rawcliffe CL, Buchler MW: Adjuvant chemotherapy with fluorouracil plus folinic acid versus gemcitabine following pancreatic cancer resection: a randomized controlled trial. JAMA 2010;304:1073-1081.

37 Oettle H, Neuhaus P, Hochhaus A, Hartmann JT, Gellert K, Ridwelski K, Niedergethmann M, Zulke C, Fahlke J, Arning MB, Sinn M, Hinke A, Riess H: Adjuvant chemotherapy with gemcitabine and long-term outcomes among patients with resected pancreatic cancer: the CONKO-001 randomized trial. JAMA 2013;310:14731481.

38 Neoptolemos JP, Stocken DD, Friess H, Bassi C, Dunn JA, Hickey H, Beger H, Fernandez-Cruz L, Dervenis C, Lacaine F, Falconi M, Pederzoli P, Pap A, Spooner D, Kerr DJ, Buchler MW: A randomized trial of chemoradiotherapy and chemotherapy after resection of pancreatic cancer. N Engl J Med 2004;350:1200-1210.

39 Biagi JJ, Raphael MJ, Mackillop WJ, Kong W, King WD, Booth CM: Association between time to initiation of adjuvant chemotherapy and survival in colorectal cancer: a systematic review and meta-analysis. JAMA 2011; 305:2335-2342.

40 Valle JW, Palmer D, Jackson R, Cox T, Neoptolemos JP, Ghaneh P, Rawcliffe CL, Bassi C, Stocken DD, Cunningham D, O’Reilly D, Goldstein D, Robinson BA, Karapetis C, Scarfe A, Lacaine F, Sand J, Izbicki JR, Mayerle J, Dervenis C, Olah A, Butturini G, Lind PA, Middleton MR, Anthoney A, Sumpter K, Carter R, Buchler MW: Optimal duration and timing of adjuvant chemotherapy after definitive surgery for ductal adenocarcinoma of the pancreas: ongoing lessons from the ESPAC-3 study. J Clin Oncol 2014;32:504-512.

41 Uesaka K, Fukutomi A, Boku N, Kanemoto H, Konishi M, Matsumoto I, Kaneoka Y, Shimizu Y, Nakamori S, Sakamoto H, Morinaga S, Kainuma O, Imai K, Sata N, Hishinuma S, Nakamura T, Kanai M, Hirano S, Yoshikawa Y, Ohashi Y: Randomized phase III trial of adjuvant chemotherapy with gemcitabine versus S-1 for patients with resected pancreatic cancer (JASPAC-01 study). J Clin Oncol 2013;31(suppl 4):abstr 145.

42 NCT01964430: Nab-paclitaxel and gemcitabine vs gemcitabine alone as adjuvant therapy for patients with resected pancreatic cancer (APACT). ClinicalTrials.gov 2013.

43 NCT02172976: Randomized multicenter phase II/III study with adjuvant gemcitabine versus neoadjuvant/ adjuvant FOLFIRINOX for resectable pancreas carcinoma. ClinicalTrials.gov 2014.

44 Vickers MM, Powell ED, Asmis TR, Jonker DJ, Hilton JF, O’Callaghan CJ, Tu D, Parulekar W, Moore MJ: Comorbidity, age and overall survival in patients with advanced pancreatic cancer - results from NCIC CTG PA.3: a phase III trial of gemcitabine plus erlotinib or placebo. Eur J Cancer 2012;48:1434-1442.

45 Heinemann V, Labianca R, Hinke A, Louvet C: Increased survival using platinum analog combined with gemcitabine as compared to single-agent gemcitabine in advanced pancreatic cancer: pooled analysis of two randomized trials, the GERCOR/GISCAD intergroup study and a German multicenter study. Ann Oncol 2007; 18:1652-1659.

46 Nakachi K, Furuse J, Ishii H, Suzuki E, Yoshino M: Prognostic factors in patients with gemcitabine-refractory pancreatic cancer. Jpn J Clin Oncol 2007;37:114-120.

47 Burris HA 3rd, Moore MJ, Andersen J, Green MR, Rothenberg ML, Modiano MR, Cripps MC, Portenoy RK, Storniolo AM, Tarassoff P, Nelson R, Dorr FA, Stephens CD, Von Hoff DD: Improvements in survival and clinical benefit with gemcitabine as first-line therapy for patients with advanced pancreas cancer: a randomized trial. J Clin Oncol 1997;15:2403-2413.

48 Philip PA, Benedetti J, Corless CL, Wong R, O’Reilly EM, Flynn PJ, Rowland KM, Atkins JN, Mirtsching BC, Rivkin SE, Khorana AA, Goldman B, Fenoglio-Preiser CM, Abbruzzese JL, Blanke CD: Phase III study comparing gemcitabine plus cetuximab versus gemcitabine in patients with advanced pancreatic adenocarcinoma: Southwest Oncology Group-directed intergroup trial S0205. J Clin Oncol 2010;28:3605-3610.

49 Kim GP, Foster NR, Salim M, Flynn PJ, Moore DF Jr, Zon R, Mowat RB, McCullough A, Meyers JP, Alberts SR: Randomized phase II trial of panitumumab (P), erlotinib (E), and gemcitabine (G) versus erlotinib-gemcitabine in patients with untreated, metastatic pancreatic adenocarcinoma. J Clin Oncol 2011;29(suppl 4):abstr 238.

50 Strumberg D, Schultheis B, Ebert MP, Kerkhoff A, Hofheinz RD, Behringer DM, Schmidt WE, Goker E, De Dosso S, Kneba M, Yalcin S, Overkamp F, Schlegel F, Dommach M, Rohrberg R, Steinmetz T, Reuter D, Bach F: Phase II, randomized, double-blind placebo-controlled trial of nimotuzumab plus gemcitabine compared with gemcitabine alone in patients (pts) with advanced pancreatic cancer (PC). J Clin Oncol 2013;31(suppl):abstr 4009 .

51 Graeven U, Kremer B, Sudhoff T, Killing B, Rojo F, Weber D, Tillner J, Unal C, Schmiegel W: Phase I study of the humanised anti-EGFR monoclonal antibody matuzumab (EMD 72000) combined with gemcitabine in advanced pancreatic cancer. Br J Cancer 2006;94:1293-1299.

52 Gourgou-Bourgade S, Bascoul-Mollevi C, Desseigne F, Ychou M, Bouche O, Guimbaud R, Becouarn Y, Adenis A, Raoul JL, Boige V, Berille J, Conroy T: Impact of FOLFIRINOX compared with gemcitabine on quality of life in patients with metastatic pancreatic cancer: results from the PRODIGE 4/ACCORD 11 randomized trial. J Clin Oncol 2013;31:23-29. 
53 Frese KK, Neesse A, Cook N, Bapiro TE, Lolkema MP, Jodrell DI, Tuveson DA: nab-Paclitaxel potentiates gemcitabine activity by reducing cytidine deaminase levels in a mouse model of pancreatic cancer. Cancer Discov 2012;2:260-269.

54 Awasthi N, Zhang C, Schwarz AM, Hinz S, Wang C, Williams NS, Schwarz MA, Schwarz RE: Comparative benefits of Nab-paclitaxel over gemcitabine or polysorbate-based docetaxel in experimental pancreatic cancer. Carcinogenesis 2013;34:2361-2369.

55 Von Hoff DD, Ramanathan RK, Borad MJ, Laheru DA, Smith LS, Wood TE, Korn RL, Desai N, Trieu V, Iglesias JL, Zhang H, Soon-Shiong P, Shi T, Rajeshkumar NV, Maitra A, Hidalgo M: Gemcitabine plus nab-paclitaxel is an active regimen in patients with advanced pancreatic cancer: a phase I/II trial. J Clin Oncol 2011;29:45484554.

56 Pelzer U, Schwaner I, Stieler J, Adler M, Seraphin J, Dorken B, Riess H, Oettle H: Best supportive care (BSC) versus oxaliplatin, folinic acid and 5-fluorouracil (OFF) plus BSC in patients for second-line advanced pancreatic cancer: a phase III-study from the German CONKO-study group. Eur J Cancer 2011;47:1676-1681.

57 Oettle H, Riess H, Stieler JM, Heil G, Schwaner I, Seraphin J, Gorner M, Molle M, Greten TF, Lakner V, Bischoff S, Sinn M, Dorken B, Pelzer U: Second-line oxaliplatin, folinic acid, and fluorouracil versus folinic acid and fluorouracil alone for gemcitabine-refractory pancreatic cancer: outcomes from the CONKO-003 trial. J Clin Oncol 2014;32:2423-2429.

58 Assaf E, Verlinde-Carvalho M, Delbaldo C, Grenier J, Sellam Z, Pouessel D, Bouaita L, Baumgaertner I, Sobhani I, Tayar C, Paul M, Culine S: 5-fluorouracil/leucovorin combined with irinotecan and oxaliplatin (FOLFIRINOX) as second-line chemotherapy in patients with metastatic pancreatic adenocarcinoma. Oncology 2011;80:301-306.

59 Hosein PJ, de Lima Lopes G Jr, Pastorini VH, Gomez C, Macintyre J, Zayas G, Reis I, Montero AJ, Merchan JR, Rocha Lima CM: A phase II trial of nab-paclitaxel as second-line therapy in patients with advanced pancreatic cancer. Am J Clin Oncol 2013;36:151-156.

60 Kalra AV, Kim J, Klinz SG, Paz N, Cain J, Drummond DC, Nielsen UB, Fitzgerald JB: Preclinical activity of nanoliposomal irinotecan is governed by tumor deposition and intratumor prodrug conversion. Cancer Res 2014; 74:7003-7013.

61 Hann B, Peth K, Wang D, Gysin S, Li S, Kullberg E, Hom Y, Goldman M, Tempero M, Park J: Lipidic nanoparticle CPT-11 in a bioluminescent orthotopic pancreas cancer model. American Association of Cancer Research Annual Meeting 2007, abstr 5648.

62 Ko AH, Tempero MA, Shan YS, Su WC, Lin YL, Dito E, Ong A, Wang YW, Yeh CG, Chen LT: A multinational phase 2 study of nanoliposomal irinotecan sucrosofate (PEP02, MM-398) for patients with gemcitabine-refractory metastatic pancreatic cancer. Br J Cancer 2013;109:920-925.

63 Von Hoff D, Li CP, Wang-Gillam A, Bodoky G, Dean A, Jameson G, Macarulla T, Lee KH, Cunningham D, Blanc JF, Hubner R, Chiu CF, Schwartsmann G, Siveke J, Braiteh F, Moyo V, Belanger B, Dhindsa N, Bayever E, Chen LT: NAPOLI-1: randomized phase 3 study of MM-398 (nal-IRI), with or without 5-fluorouracil and leucovorin versus 5 -fluorouracil and leucovorin, in metastatic pancreatic cancer progressed on or following gemcitabinebased therapy. Ann Oncol 2014;25(suppl 2):abstr 0-0003.

64 Beatty GL, Chiorean EG, Fishman MP, Saboury B, Teitelbaum UR, Sun W, Huhn RD, Song W, Li D, Sharp LL, Torigian DA, O'Dwyer PJ, Vonderheide RH: CD40 agonists alter tumor stroma and show efficacy against pancreatic carcinoma in mice and humans. Science 2011;331:1612-1616.

65 Clark CE, Hingorani SR, Mick R, Combs C, Tuveson DA, Vonderheide RH: Dynamics of the immune reaction to pancreatic cancer from inception to invasion. Cancer Res 2007;67:9518-9527.

66 Hurwitz H, Uppal N, Wagner SA, Bendell JC, Beck JT, Wade S, Nemunaitis JJ, Stella PJ, Pipas JM, Wainberg ZA, Manges R, Garrett WM, Hunter DS, Clark J, Leopold L, Levy RS, Sandor V: A randomized double-blind phase 2 study of ruxolitinib (RUX) or placebo (PBO) with capecitabine (CAPE) as second-line therapy in patients (pts) with metastatic pancreatic cancer (mPC). J Clin Oncol 2014;32(suppl):abstr 4000.

67 Ramakrishnan R, Assudani D, Nagaraj S, Hunter T, Cho HI, Antonia S, Altiok S, Celis E, Gabrilovich DI: Chemotherapy enhances tumor cell susceptibility to CTL-mediated killing during cancer immunotherapy in mice. J Clin Invest 2010;120:1111-1124.

68 Lesterhuis WJ, Salmons J, Nowak AK, Rozali EN, Khong A, Dick IM, Harken JA, Robinson BW, Lake RA: Synergistic effect of CTLA-4 blockade and cancer chemotherapy in the induction of anti-tumor immunity. PLoS One 2013;8:e61895.

69 Royal RE, Levy C, Turner K, Mathur A, Hughes M, Kammula US, Sherry RM, Topalian SL, Yang JC, Lowy I, Rosenberg SA: Phase 2 trial of single agent ipilimumab (anti-CTLA-4) for locally advanced or metastatic pancreatic adenocarcinoma. J Immunother 2010;33:828-833.

70 Le DT, Wang-Gillam A, Picozzi V Jr, Greten TF, Crocenzi TS, Springett GM, Morse M, Zeh H, Cohen DJ, Fine RL, Onners B, Uram JN, Laheru D, Murphy A, Skoble J, Lemmens E, Grous JJ, Dubensky T, Brockstedt DG, Jaffee EM: A phase 2, randomized trial of GVAX pancreas and CRS-207 immunotherapy versus GVAX alone in patients with metastatic pancreatic adenocarcinoma: updated results. J Clin Oncol 2014;32(suppl 3):abstr 177.

71 NCT02004262: Safety and efficacy of combination Listeria/GVAX pancreas vaccine in the pancreatic cancer setting (ECLIPSE). ClinicalTrials.gov 2013.

72 Klinkenbijl JH, Jeekel J, Sahmoud T, van Pel R, Couvreur ML, Veenhof CH, Arnaud JP, Gonzalez DG, de Wit LT, Hennipman A, Wils J: Adjuvant radiotherapy and 5-fluorouracil after curative resection of cancer of the pancreas and periampullary region: phase III trial of the EORTC gastrointestinal tract cancer cooperative group. Ann Surg 1999;230:776-782; discussion 782-784. 
73 Regine WF, Winter KA, Abrams R, Safran H, Hoffman JP, Konski A, Benson AB, Macdonald JS, Rich TA, Willett CG: Fluorouracil-based chemoradiation with either gemcitabine or fluorouracil chemotherapy after resection of pancreatic adenocarcinoma: 5-year analysis of the U.S. Intergroup/RTOG 9704 phase III trial. Ann Surg Oncol 2011;18:1319-1326.

74 Lee MG, Lee SH, Lee SJ, Lee YS, Hwang JH, Ryu JK, Kim YT, Kim DU, Woo SM: 5-Fluorouracil/leucovorin combined with irinotecan and oxaliplatin (FOLFIRINOX) as second-line chemotherapy in patients with advanced pancreatic cancer who have progressed on gemcitabine-based therapy. Chemotherapy 2013;59: 273-279.

75 Zaniboni A, Aitini E, Barni S, Ferrari D, Cascinu S, Catalano V, Valmadre G, Ferrara D, Veltri E, Codignola C, Labianca R: FOLFIRI as second-line chemotherapy for advanced pancreatic cancer: a GISCAD multicenter phase II study. Cancer Chemother Pharmacol 2012;69:1641-1645.

76 Soares HP, Bayraktar S, Blaya M, Lopes G, Merchan J, Macintyre J, Mayo C, Green MR, Silva O, Levi J, Walker G, Rocha-Lima CM: A phase II study of capecitabine plus docetaxel in gemcitabine-pretreated metastatic pancreatic cancer patients: CapTere. Cancer Chemother Pharmacol 2014;73:839-845.

77 Yoo C, Hwang JY, Kim JE, Kim TW, Lee JS, Park DH, Lee SS, Seo DW, Lee SK, Kim MH, Han DJ, Kim SC, Lee JL: A randomised phase II study of modified FOLFIRI.3 vs modified FOLFOX as second-line therapy in patients with gemcitabine-refractory advanced pancreatic cancer. Br J Cancer 2009;101:1658-1663.

78 Cereda S, Reni M, Rognone A, Fugazza C, Ghidini M, Ceraulo D, Brioschi M, Nicoletti R, Villa E: Salvage therapy with mitomycin and ifosfamide in patients with gemcitabine-resistant metastatic pancreatic cancer: a phase II trial. Chemotherapy 2011;57:156-161.

79 Xiong HQ, Varadhachary GR, Blais JC, Hess KR, Abbruzzese JL, Wolff RA: Phase 2 trial of oxaliplatin plus capecitabine (XELOX) as second-line therapy for patients with advanced pancreatic cancer. Cancer 2008; 113: 2046-2052.

80 Demols A, Peeters M, Polus M, Marechal R, Gay F, Monsaert E, Hendlisz A, Van Laethem JL: Gemcitabine and oxaliplatin (GEMOX) in gemcitabine refractory advanced pancreatic adenocarcinoma: a phase II study. Br J Cancer 2006;94:481-485.

81 Dragovich T, Laheru D, Dayyani F, Bolejack V, Smith L, Seng J, Burris H, Rosen P, Hidalgo M, Ritch P, Baker AF, Raghunand N, Crowley J, Von Hoff DD: Phase II trial of vatalanib in patients with advanced or metastatic pancreatic adenocarcinoma after first-line gemcitabine therapy (PCRT 04-001). Cancer Chemother Pharmacol 2014;74:379-387.

82 Kim YJ, Bang S, Park JY, Park SW, Chung JB, Song SY: Phase II study of 5-fluorouracil and paclitaxel in patients with gemcitabine-refractory pancreatic cancer. Cancer Chemother Pharmacol 2009;63:529-533.

83 Chung JW, Jang HW, Chung MJ, Park JY, Park SW, Chung JB, Song SY, Bang S: Folfox4 as a rescue chemotherapy for gemcitabine-refractory pancreatic cancer. Hepatogastroenterology 2013;60:363-367. 